\title{
Development of a mycotic aneurysm within 4 days
}

\section{Figure Cranial CT and CT angiography}

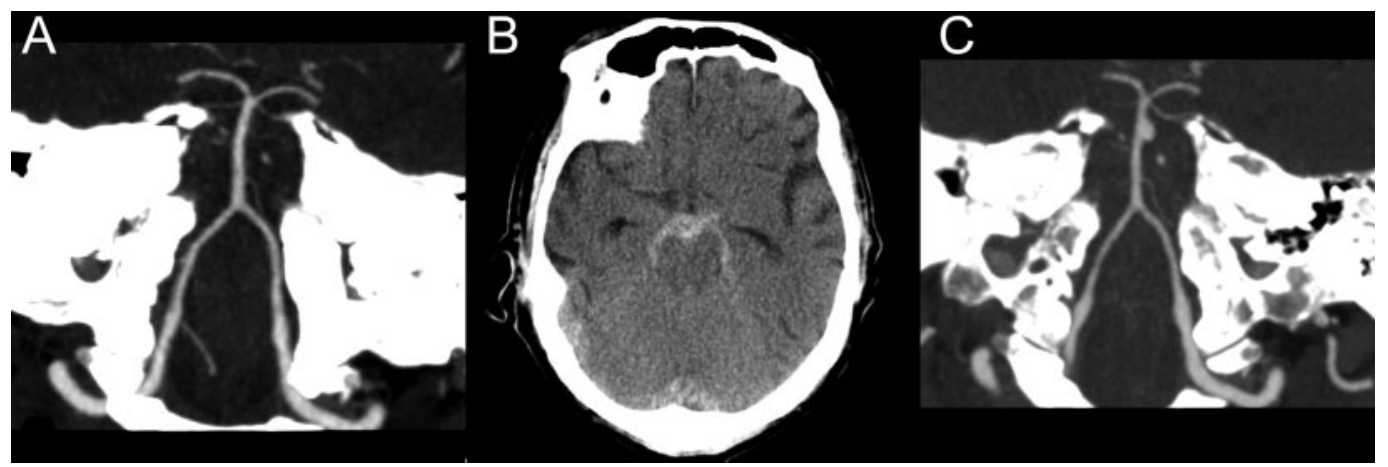

Initial CT angiography revealed no remarkable abnormalities (A). Four days later, a head CT showed subarachnoidal blood in the basal cisterns (B). A newly formed mycotic aneurysm of the basilar artery was identified by CT angiography (C).

A 60-year-old man with chronic myelomonocytic leukemia was admitted for bacterial meningitis. Initial cranial CT and CT angiography (figure, A) were normal. Four days after admission, the patient became comatose. A subsequent cranial CT (figure, B) revealed a subarachnoid hemorrhage, and CT angiography (figure, C) showed a newly developed aneurysm of the basilar artery. We diagnosed a mycotic aneurysm due to acute meningitis. Apart from endocarditis, meningitis is a frequent cause of mycotic aneurysms. ${ }^{1}$ Cases of such rapid aneurysmal development are extremely rare, but should be thought of particularly in immunocompromised patients. ${ }^{2}$

J. Minnerup, $M D$, M. Schilling, $M D, H$. Wersching, $M D$, C. Ölschläger, $M D$, W.-R. Schäbitz, $M D$, T. Niederstadt, MD, R. Dziewas, MD, Münster, Germany

Disclosure: The authors report no disclosures.

Address correspondence and reprint requests to Dr. J. Minnerup, Universitätsklinikum Münster, Klinik und Poliklinik für Neurologie, Albert-Schweitzer-Straße 33, 48149 Münster, Germany; minnerup@uni-muenster.de

1. Kannoth S, Iyer R, Thomas SV, et al. Intracranial infectious aneurysm: presentation, management and outcome. J Neurol Sci 2007;256:3-9.

2. Wilson WR, Hawrych A, Olan W. Rapid development of bilateral internal carotid artery aneurysm from sphenoid sinus aspergillosis. Skull Base Surg 1998;8:211-214. 


\section{Neurology}

\section{Development of a mycotic aneurysm within 4 days}

J. Minnerup, M. Schilling, H. Wersching, et al.

Neurology 2008;71;1745

DOI 10.1212/01.wnl.0000335247.86599.6f

\section{This information is current as of November 17, 2008}

\section{Updated Information \&} Services

References

Subspecialty Collections

Permissions \& Licensing

Reprints including high resolution figures, can be found at: http://n.neurology.org/content/71/21/1745.full

This article cites 2 articles, 0 of which you can access for free at: http://n.neurology.org/content/71/21/1745.full\#ref-list-1

This article, along with others on similar topics, appears in the following collection(s):

Meningitis

http://n.neurology.org/cgi/collection/meningitis

Subarachnoid hemorrhage

http://n.neurology.org/cgi/collection/subarachnoid_hemorrhage

Information about reproducing this article in parts (figures,tables) or in its entirety can be found online at:

http://www.neurology.org/about/about_the_journal\#permissions

Information about ordering reprints can be found online:

http://n.neurology.org/subscribers/advertise

Neurology ${ }^{\circledR}$ is the official journal of the American Academy of Neurology. Published continuously since 1951, it is now a weekly with 48 issues per year. Copyright . All rights reserved. Print ISSN: 0028-3878. Online ISSN: 1526-632X.

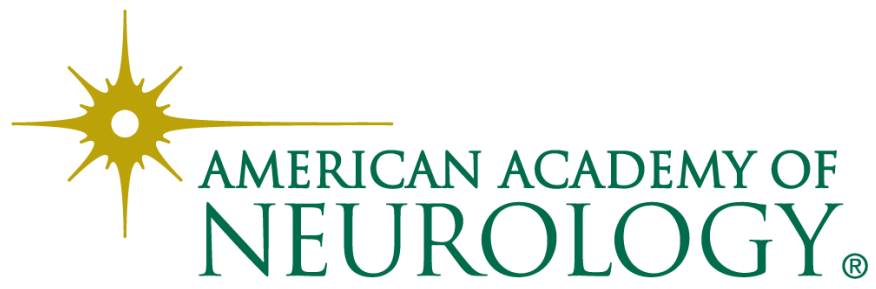

